\title{
Pengaruh Kemampuan Tata Bahasa dan Kosa Kata terhadap Penguasaan Menulis Paragraf Narasi pada Siswa Kelas X SMAN Negeri 10 Kota Jambi
}

\author{
Elviza \\ SMAN 10 Kota Jambi \\ Correspondence email: elvizaviza16@gmail.com
}

\begin{abstract}
Abstrak: Penelitian ini untuk mengetahui pengaruh keterampilan tata bahasa terhadap penguasaan menulis paragraf naratif. Hal ini untuk mengetahui pengaruh keterampilan kosakata terhadap penguasaan menulis paragraf naratif dan untuk mengetahui pengaruh keterampilan tata bahasa dan kosakata terhadap penguasaan menulis paragraf naratif. Populasi dan sampel dalam penelitian ini adalah siswa kelas X jurusan IPA dan IPS di SMA Negeri 10 Kota Jambi yang berjumlah 245 orang. Berdasarkan hasil penelitian di atas diperoleh hasil bahwa sebanyak $75(30,61 \%)$ siswa memiliki penguasaan kosakata tinggi, 103 siswa $(42,04 \%)$ tingkat penguasaan kosakata sedang, dan sebanyak 67 siswa. (27,34\%) memiliki tingkat penguasaan. rendah. Berdasarkan hasil penelitian penguasaan kosakata sebanyak 40 siswa atau 16,32\%, penguasaan kosakata sedang sebanyak 145 siswa $(59,18 \%)$ dan penguasaan kosakata siswa yang berada pada kategori rendah sebanyak 60 siswa. (24,48\%). ). Berdasarkan hasil penelitian penguasaan kosakata sebanyak 40 siswa atau 16,32\%, penguasaan kosakata sedang sebanyak 145 siswa (59,18\%) dan penguasaan kosakata siswa yang berada pada kategori rendah sebanyak 60 siswa. $(24,48 \%)$.
\end{abstract}

Kata Kunci: Tata bahasa, kosa kata, menulis, paragraph narasi

\begin{abstract}
Abstrack: This study to know determine the effect of grammar skills on mastery of writing narrative paragraphs. This is to determine the effect of vocabulary skills on writing mastery of narrative paragraphs and to determine the effect of grammar and vocabulary skills on writing mastery of narrative paragraphs. The population and sample in this study were students of class $X$ majoring in science and social studies at SMA Negeri 10 Jambi City, totaling 245 people. Based on the results of the research above, it was obtained that as many as 75 (30.61\%) students had a high level of vocabulary mastery, 103 students (42.04\%) had a moderate level of vocabulary mastery, and as many as 67 students (27.34\%) had a mastery level. low. Based on the results of the study, vocabulary mastery was as many as 40 students or $16.32 \%$, students who had a moderate level of vocabulary mastery were 145 students (59.18\%) and vocabulary mastery of students who were in the low category were 60 students (24.48\%). ). Based on the results of the study, vocabulary mastery was as many as 40 students or $16.32 \%$, students who had a moderate level of vocabulary mastery were 145 students (59.18\%) and vocabulary mastery of students who were in the low category were 60 students $(24.48 \%)$.
\end{abstract}

Keywords: Grammar, vocabulary, writing, narrative paragraph

\section{PENDAHULUAN}

Manusia mempergunakan bahasa sebagai sarana komunikasi vital dalam hidup ini. Bahasa adalah milik salah satu ciri pembeda utama manusia dari mahkluk hidup lainnya di dunia ini (Tarigan, 2011). Dengan demikian, bahasa memiliki peranan pentig dalam kegiatan berkomunikasi baik lisan maupun tulisan. Dengan bahasa seseorang dapat mengutarakan keinginan, menjelaskan ide, mengungkapkan pikiran dan gagasannya pada orang lain. Dengan bahasa seseorang dapat saling memahami perasaan dan mencurahkan gagasan pikiran dalam bentuk tulisan atau karya tulis. Selanjutnya pembelajaran Bahasa Indonesia bertujuan memberikan keterampilan meliputi keterampilan menyimak, berbicara, membaca dan menulis. Keempat keterampilan tersebut saling berkitan satu sama lain. Keterampilan menyimak harus dikuasai dikuasai karena dengan kegiatan menyimak, seseorang dapat mengenal bunyi yang membedakan arti, memperoleh kosakata dan mengetahui gramatikal.

Keterampilan berbicara juga dikuasai seseorang melalui kegiatan menyimak yang telah mengenal bunyi-bunyi serta kosakata dan tata bahasa. Keterampilan membaca harus dimiliki oleh setiap orang karena melalui membaca seseorang memperoleh kosakata baru yang dapat membantu dan memperkaya perbendaharaan kata sehingga lebih terampil.

Kosakata mempunyai peranan penting karena muncul dalam setiap keterampilan bahasa. Pemahaman kosakata sangatlah penting dalam setiap belajar bahasa. Penguasaan kosakata juga dibutuhkan untuk berkomunikasi dengan masyarakat. Mereka yang mempunyai banyak gagasan, atau dengan kata lain mereka yang luas kosakatanya dapat dengan mudah dan lancar mengadakan komunikasi dengan orang lain (Keraf : 2004). Keterampilan menulis merupakan kegiatan menuangkan ide dan gagasannya dalam bentuk tulisan. Pemilihan kosakata yang tepat akan membantu pembaca memahami makna dari tulisan tersebut. Mereka yang luas kosakatanya akan memiliki kemampuan yang tinggi untuk memilih kata yang harmonis. 
Permasalahan yang biasanya terjadi dalam menulis narasi adalah kurangnya penguasaan kosakata, padahal kosakata menentukan seberapa terampil seseorang dalam berbahasa. Kualitas keterampilan berbahasa seseorang jelas bergantung kepada kuantitas dan kualitas kosakata yang dimiliknya (Tarigan, 2008). Semakkin kaya kosakata yang kita miliki, maka semakin besar pula kemungkinan keterampilan berbahasa yang kita miliki. Salah satu cara yang dapat dilakukan untuk menumbuhkan dan mengembangkan kemampuan menulis adalah meningkatkan penguasaan kosakata dan tata bahasa. Kosakata merupakan bahan utama untk merealisasikan ide dan gagasan, sedangkan tata bahasa merupakan seperangkat kaidah kebahasaan yang digunakan untuk menyususn kata dan kalimat, sehingga menjadi kalimat yang baik dan benar (Nurhadi, 1995). Kosakata mempunyai peranan penting karena muncul dalam setiap keterampilan bahas. Pemahaman kosakata sangatlah penting dalam setiap belajar bahasa. Penguasaan kosakata juga dibutuhkan ntuk berkomunikasi dengan masyarakat.

\section{METODE}

\section{Variabel Penelitian}

Penelitian ini memiliki tiga variabel, yaitu $\left(\mathrm{X}_{1}\right)$ Kemampuan Tata Bahasa, $\left(\mathrm{X}_{2}\right)$ Kemampuan Kosa Kata dan $\mathrm{Y}$ Penguasaan Menulis Paragraf Narasi

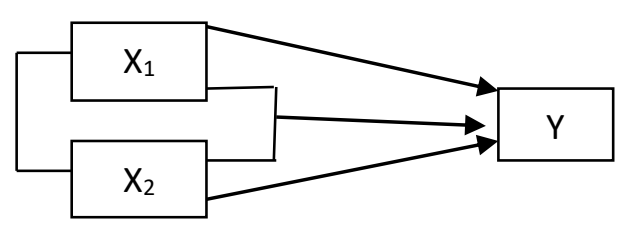

Gambar 1 . paradigma Penelitian

Keterangan :

X1 : Kemampuan Tata Bahasa

X2 : Kemampuan Kosa Kata

Y : Penguasaan Menulis Paragraf Narasi

\section{Desain Penelitian}

Penelitian ini merupakan penelitian yang ingin mengetahui pengaruh antara ketiga variabel yaitu variabel Kemampuan Tata Bahasa, Variabel Kemampuan Kosa Kata dan Variabel Penguasaan Menulis Paragraf Narasi.

\section{Populasi dan Sampel}

Populasi dan sampel dalam penelitian ini adalah siswa kelas X jurusan IPA dan IPS SMA Negeri 10 Kota Jambi yang berjumlah 245 orang.

\section{Tekhnik Pengumpulan dan Analisis Data}

\section{a. Uji Normalitas}

Uji normalitas dimaksudkan untuk menguji apakah dalam model regresi, variabel pengganggu atau residual mempunyai distribusi normal (Suhaimi Arikunto : 2010).

b. Uji Linearitas

Uji linearitas adalah untuk mengetahui apakah hubungan antara variabel bebas dan variabel terikat berbentuk linear atau tidak.

c. Uji Interkorelasi

Uji interkorelasi untuk mengetahui apakah antarvariabel bebas terdapat multikoliniaritas atau tidak.

\section{HASIL DAN PEMBAHASAN}

\section{Pengaruh Kemampuan Tata Bahasa terhadap Penguasaan Menulis Paragraf Narasi}

Berdasarkan hasil penelitian di atas diperoleh data sebanyak $75(30,61 \%)$ siswa memiliki tingkat penguasaan kosakata tinggi, terdapat 103 siswa $(42,04 \%)$ memiliki tingkat penguasaan kosakata sedang, dan sebanyak 67 siswa $(27,34 \%)$ memiliki tingkat penguasaan rendah.

Penguasaan tata bahasa berkaitan dengan kemampuan tentang kata pada tataran morfologi, dan kemampuan tentang kalimat pada tataran sintaksis. Menulis merupakan keterampilan berbahasa yang paling tinggi tinggi tingkatanya (Suriamiharja, 1966). Berdasarkan uji korelasi product moment, diketahui bahwa rhitung penguasaan tata

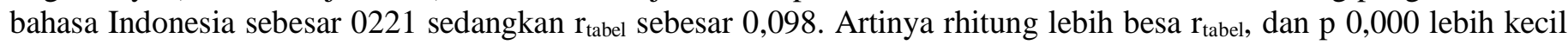
dari taraf signifikansi $5 \%(0,000<0,05)$. Berdasarkan pada analisis di atas dapt disimpulkan bahwa penelitian ini 
Elviza, Pengaruh Kemampuan Tata Bahasa dan Kosa Kata terhadap Penguasaan Menulis Paragraf Narasi pada Siswa Kelas X SMAN Negeri 10 Kota Jambi

berhasil membuktikan bahwa terdapat pengaruh yang signifikan antara kemampuan tata bahasa terhadap kemampuan menulis paragraf narasi.

\section{Pengaruh Kemampuan Kosakata terhadap Penguasaan Menulis Paragraf Narasi}

Berdasaran hasil penelitian, penguasaan kosakata yaitu sebanyak 40 siswa atau 16,32\%, siswa yang memiliki tingkat penguasaan kosakata kategori sedang sebanyak 145 siswa $(59,18 \%)$ dan penguasaan kosakata siswa yang berada pada kategori rendah sebanyak 60 siswa $(24,48 \%)$.

Berdasarkan penelitian di atas dapat disimpulkan bahwa kemampuan kosakata bukanlah keterampilan yang sederhana, karena mencakup pengenalan, pemilihan dan penerapan. Kemampuan kosa kata juga bukan merupakan proses yang spontan melainkan proses menuju kemampuan kosa kata yang baik dan benar (Dale, 2008).

Penguasaan kosakata mempunyai sumbangan yang berarti terhadap kemampuan menulis parafraf narasi. Kosakata mempunyai peranan penting dalam proses membuat paragraf narasi. Penguasaan kosakata yang baik dan benar akan membuat kita lebih mudah membuat tulisan yang baik dan benar juga (Keraf, 2004).

Berdasarkan uji korelasi product moment diketahui, bahwa rhitung penguasaan kosakata sebesar 0,164 sedangkan rtabel sebesar 0,098. Artinya rhitung lebih besar dari rtabel, dan p 0,001 lebih kecil dari taraf signifikan $5 \%(0,001<0,5)$. Dapat disimpulkan bahwa terdapt pengaruh yang signifikan antara kemampuan kosakata terhadap penguasaan menulis paragraf narasi.

\section{Pengaruh Kemampuan Kosakata dan Tata Bahasa Terhadap Penguasaan Menulis Paragraf Narasi}

Berdasarkan perhitungan statistik uji simulta $F$ diperoleh nilai $F_{\text {reg }}$ sebesa 10,950 lebih besar dari $F_{\text {tabel }}$ sebanyak 3,02 dan nilai signifikan 0,000 lebih kecil dari 0,05. Melalui analisis regresi linear berganda diperoleh koefisien determinasi sebesar 0,060 yang berarti bahwa $6 \%$ variasi dalam variabel penelitian berpengaruh terhadap variabel lainnya yaitu kemampuan kosa kata dan kemampuan tata bahasa, sedangkan 95\% sisanya diperoleh dari variabel lain di luar penelitian. Hal ini membuktikan bahwa terdapat pengaruh yang sifnifian antara kemampuan kosakata dan tata bahasa terhadap penguasaan menulis paragraf narasi.

\section{SIMPULAN}

Berdasarkan data yang diperoleh dari hasil penelitian serta hasil analisis statistik yang telah dilakukan, dapat diambil kesimpulan sebagai berikut :

1. Terdapat pengaruh yang signifikan antara Pengaruh Kemampuan Tata Bahasa terhadap Penguasaan Menulis Paragraf Narasi dengan perolehan data sebanyak $75(30,61 \%)$ siswa memiliki tingkat penguasaan kosakata tinggi, terdapat 103 siswa $(42,04 \%)$ memiliki tingkat penguasaan kosakata sedang, dan sebanyak 67 siswa $(27,34 \%)$ memiliki tingkat penguasaan rendah.

2. Terdapat pengaruh yang signifikan antara Pengaruh Kemampuan Kosakata terhadap Penguasaan Menulis Paragraf Narasi dengan perolehan data sebanyak 40 siswa atau 16,32\%, siswa yang memiliki tingkat penguasaan kosakata kategori sedang sebanyak 145 siswa $(59,18 \%)$ dan penguasaan kosakata siswa yang berada pada kategori rendah sebanyak 60 siswa $(24,48 \%)$.

3. Terdapat pengaruh yang signifikan secara bersma-sama antara Pengaruh Kemampuan Tata Bahasa dan Kosakata terhadap Penguasaan Menulis Paragraf Narasi dengan perolehan data sebanyak.

\section{Saran}

Sebelum pembelajaran dimulai, hendaknya diberikan penjelaskan kepada guru dan siswa mengenai tujuan pembelajaran yang hendak dicapai

\section{DAFTAR PUSTAKA}

Akhadiah, Sabarti, dkk. (1994). Pembinaan Kemampuan Menulis Bahasa Indonesia. Jakarta : Erlangga

Alwi, Hasan dkk. (2003). Tata Bahasa Baku Bahasa Indonesia. Edisi Ketiga. Jakarta : Balai Pustaka

Arikunto, Suharsimi. (2010). Prosedur Penelitian Suatu Pendekatan Praktik. Jakarta : Rineka Cipta

Darmadi, Kaswan. (1996). Meningkatkan Kemampuan Menulis Panduan Untuk Mahasiswa dan Calon Mahasiswa . Yogyakarta : Andi Offset

Ghazali, A. Syukur (2010). Pembelajaran Keterampilan Berbahasa : dengan Pendekatan Komunikatif - Interaktif. Bandung : Refika Aditama

Keraf, Gorys. (2004). Diksi dan Gaya Bahasa. Jakarta : Gramedia Pustaka Umum

Nurhadi. (1995). Tata Bahasa Pendidikan Landasan Penyusunan Buku Pelajaran Bahasa. Semarang : IKIP Semarang Press.

Tarigan, Henry Guntur. (2011). Pengajaran Kosakata. Bandung : Angkasa

Tarigan, Henry Guntur. (2008). Menulis Sebagai Suatu Keterampilan Berbahasa. Bandung : Angkasa 